\title{
Corpus Callosum Size, is There a Sexual Difference?
}

\author{
Tamaño del Cuerpo Calloso, ¿Existe una Diferencia Sexual?
}

\author{
Mohammad Yasin* \& Reza Mastery Farahani**
}

YASIN, M. \& FARAHANI, R. M. Corpus callosum size, is there a sexual difference? Int. J. Morphol., 33(1):96-99, 2015.

\begin{abstract}
SUMMARY: Physical anthropometry is a subdivision of human anatomy science, which has uses in medical industries. A lot of studies showed that genetic, racial, and socioeconomic factors and educational background play rule in anthropometry. We aim this study to determine the presence of differences between gender and corpus callosum size. MRIs were collected from Ardebil and Kermanshah states done in 2013, the participants were informed about this study. They were selected based on age more than 20-years old, absence of demyelization and degenerative diseases, clean history of for neurosurgery, and previous cerebrovascular accidents. MRIs were analyzed by PmsDview program in the midsagittal section by using 9 landmarks, and the data was analyzed by SPSS 19.0. The mean corpus callosum in men was $551.9547 \pm 130.55 \mathrm{~mm}^{2}$, and $613.2353 \pm 99.98 \mathrm{~mm}^{2}$, and by using t-test $(\mathrm{p}<0.05)$, there was no difference in corpus callosum size in both genders. By comparing the results of this study results and other studies we believe that genetic, racial factors, beside education background play great rule to determine corpus callosum size. We suggest that such research to be done in other states of Iran, and Middle East and Asian countries which can confirm genetic and racial factors in anthropometry.
\end{abstract}

KEY WORDS: Corpus callosum; Sex-related size; Sex-related; Anthropometry; Iran; MRI; Sexual dimorphism.

\section{INTRODUCTION}

Anthropometry is a science of studying the human body size and dimensions, which has purpose of determining the size, weight, and length of different parts of human body, which can be utilized to study growth and development in pediatric-age group, and the ability of learning and developing new abilities. Anthropometry also can be used in medical industries and military devices (Cameron, 1978; NHANES, 2007).

The important site of anthropometry can be understood by reading CAESAR project, and the money spent on this project (Robinette et al., 2002), where we can understand its viable part in medical industries, and other health projects (Robinette et al.).

Anthropometry can be affected by numerous factors such as age, sex, race, and socioeconomic factors. These factors lead to develop standard indices and formulas to calculate size, length, and height of human body parts. Therefore, anthropometry results will not have dynamic effect in some races and countries (Farahani \& Nooranipour, 2008).
Corpus callosum is one of three cerebral commissure fibers that connect the two hemispheres together. Cerebral commissure fibers are raised around the $5^{\text {th }}$ week from a thin layer of embryonic lamina terminalis; this layer becomes enlarged and gives anterior, hippocampal, and corpus callosum. Corpus callosum arise around the fetal period and can be identified around the $11^{\text {th }}-12^{\text {th }}$ week after ovulation (His, 1889; Hochstetter, 1919; Rakic \& Yakovlev, 1968).

Corpus callosum is seen as arched shape object in the midsagittal view, which is consisted of four parts; Rostrum, Genu, Body, and Splenium. The anterior part of frontal lobes are communicated via genu, while the rest of frontal lobes and parietal lobes are connected by the body of corpus callosum, Splenium connects the anterior parts of temporal lobes and occipital lobes together (Snell, 2010; Waxman, 2009; Carpenter, 1991; Drake, 2010; Patestas \& Gartner, 2006).

Fifty individuals were participated in Erdugan study to compare the corpus callosum size which showed that difference in corpus callosum size is favorable to men

\footnotetext{
* Faculty of Medicine, Shahid Beheshti University of Medical Sciences, Tehran, Iran.

** Department of Anatomy, Shahid Beheshti University of Medical Sciences, Tehran, Iran.
} 
(Erdogan et al., 2005). Gupta et al. (2008), in 2008 showed that the length between Splenium and superior calliculus in men is greater than in women in cadavers aged from 20 to 60 years. Mourgela et al. (2007), studied the size of corpus callosum in 21 female and 14 male participated in the study, which showed that length of the genu and the size of corpus callosum is greater in male. Along with that Bruner et al. (2012) showed that the size of corpus callosum is not sexdependent, but mainly dependent on the whole body size. This study is established to determine the differences in corpus callosum related to sex.

\section{MATERIAL AND METHOD}

Study population. Participants were selected based on age more than 20-years and less than 80-years that have clean medical history for demyelization and degenerative diseases, with no previous history of cerebrovascular accidents, and neurosurgery, and clean MRI for occupying lesions. All participants were from Ardabil and Kermanshah states and were informed about the study and consent forms were signed. The included participants were 15 men and 15 women. All MRIs were analyzed by PmsDview program by radiologist in 9 landmarks (Fig. 1).

Analysis. Thirty individuals were included in this study, 15 men and 15 women, aged from 20-years to 74-years with mean age $39.37 \pm 13.7$ year. The data was analyzed by SPSS19.0.

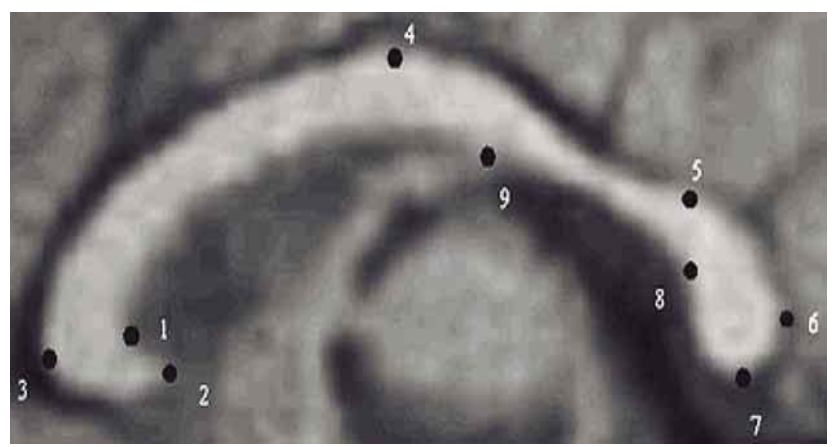

Fig. 1. Landmarks used to calculated corpus callosum size.

\section{RESULTS AND DISCUSSION}

The mean corpus callosum size was $528.59 \mathrm{~mm}^{2}$, which was $551.9547 \pm 130.55 \mathrm{~mm}^{2}$ in men, and $613.2353 \pm 99.98 \mathrm{~mm}^{2}$ in women. The independent t-test was used with hypothesis that there is relationship between sex and corpus callosum size $\mathrm{p}<0.05$, which revealed no relationship between sex and corpus callosum size (Table I, Fig. 2).

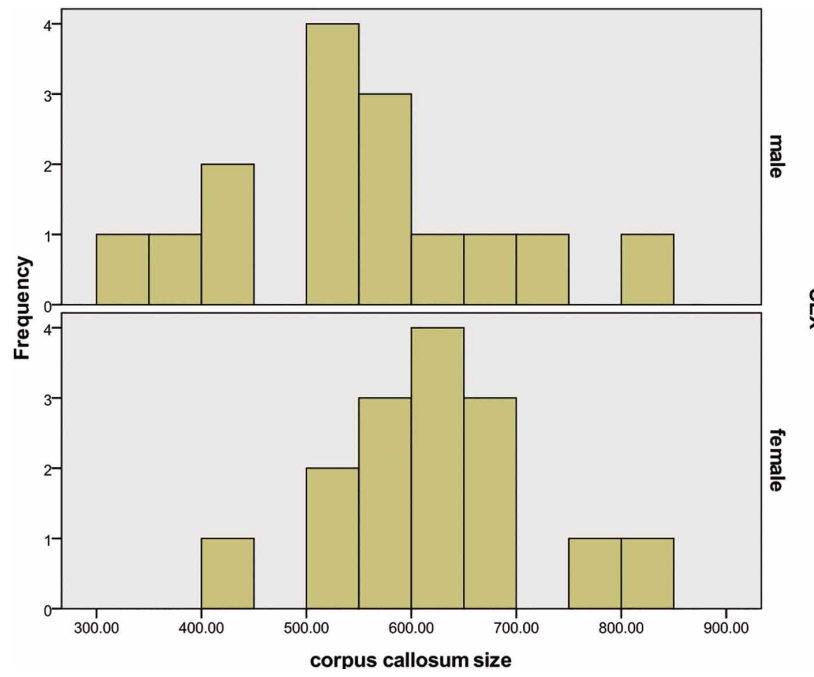

Fig. 2. Relationship of sex with corpus callosum size.

Corpus callosum provides communication between the two cerebral hemispheres, in which intelligence and creativity of human-kind can be achieved in better way (Giedd et al., 1999).

Egaas et al. (1995), studies 51 acoustic patients aged from 3-42 years and showed that corpus size is reduced in them. Poltana et al. (2001) illustrated that the corpus callosum size is equal in Thai people, which showed the mean size in men was $465 \mathrm{~mm}^{2}$ and $478 \mathrm{~mm}^{2}$ in women. The results of the Poltana et al. study are constant with this study's results. Even though the result was similar, the size in this study was greater in both male and female participants,

Table I. t-test and relationship of sex and corpus callosum size.

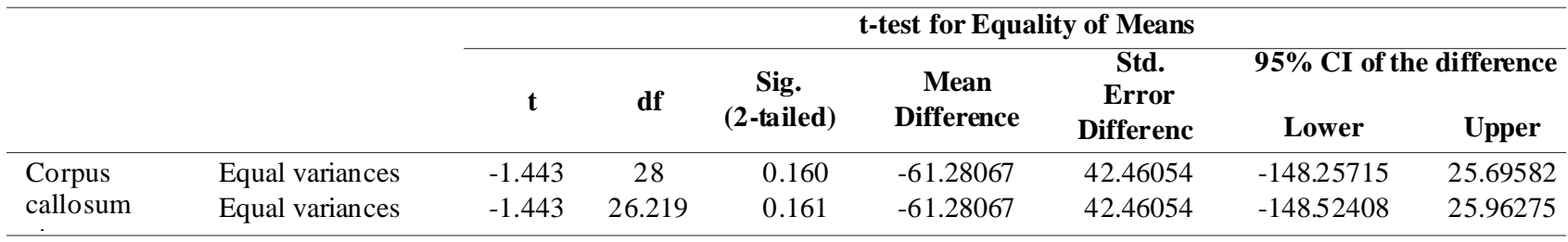


which can point to genetic and racial factors. The result is also consistent with Mourgela et al. study. Also Ozdenir et al. (2007), showed that corpus callosum size is similar in both sexes.

Luders et al. (2003) showed that hand preference and sex affect the direction of relationship between asymmetry of sulcus and Callosal areas. Sullivan et al. (2001), demonstrated that corpus callosum size is different in both genders and it is not controlled by increasing in age. Lee et al. (2003) studied the size of corpus callosum in musicians and non-musicians and showed that there is no difference in corpus callosum size among female participants in both categories, but in men there was a significant difference in size especially in anterior part of corpus callosum. All of these studies illustrate that corpus callosum size can be different in both sexes not based on their biologic sex but because of some factors interfere with ability of creating more communication between the two hemispheres. Mainly, corpus callosum size is not sex-related, but many factors play rule in its size; degenerative and demyelization disease affecting the white matter, learning abilities, individual hand-preference, languages influences, mathematical abilities, beside that genetic and racial factors, and socioeconomic situation have significant rule.

In summary Callosal size mainly not related to gender but affected by genetic, racial, socioeconomic, and learning abilities. We suggest that such studies to be done in Middle East and Asian countries to prove that the factors mentioned above can play significant rule in corpus callosum size.

YASIN, M. \& FARAHANI, R. M. Tamaño del cuerpo calloso. ¿Existe una diferencia sexual? Int. J. Morphol., 33(1):96-99, 2015.

RESUMEN: La antropometría física es una rama de la anatomía humana utilizada en las industrias médicas. Una gran cantidad de estudios ha demostrado que factores genéticos, raciales y socioeconómicos, así como antecedentes educativos forman parte de las reglas en la antropometría. Nuestro objetivo fue determinar la presencia de diferencias entre el sexo y el tamaño del cuerpo calloso. Se obtuvieron imágenes de resonancia magnética (IRM) pertenecientes a sujetos de los estados de Ardebil y Kermanshah en Irán, el año 2013. Los participantes fueron informados acerca del estudio y seleccionados en base a la edad y debían ser mayores de 20 años. Fueron incluidos casos con ausencia de desmielinización o enfermedades degenerativas, un historial sin antecedentes de neurocirugía o accidentes cerebrovasculares previos. Las IRM fueron analizadas con el programa PmsDview en la sección sagital mediana usando 9 puntos de referencia; los datos se analizaron con el programa SPSS 19.0. El tamaño promedio del cuerpo calloso en los hombres fue 551,9547 $\pm 130,55$ $\mathrm{mm}^{2}$, y en mujeres $613,2353 \pm 99,98 \mathrm{~mm}^{2}$. Mediante el uso de la prueba $\mathrm{t}(\mathrm{p}<0,05)$, no hubo diferencia en el tamaño del cuerpo calloso en ambos sexos. Al comparar estos resultados con otros estudios, existen factores genéticos, raciales, además de la educación, que juegan un papel importante al determinar el tamaño del cuerpo calloso. Sugerimos que este tipo de investigación que se realice en otros estados de Irán, el Medio Oriente y en los países asiáticos, para confirmar que los factores genéticos y raciales modifican la antropometría.

PALABRAS CLAVE: Cuerpo calloso; Relación tamaño sexo; Antropometría; Iran; IRM; Dimorfismo sexual.

\section{REFERENCES}

Bruner, E.; de la Cuétara, J. M.; Colom, R. \& Martin-Loeches, M. Gender-based differences in the shape of the human corpus callosum are associated with allometric variations. J. Anat., 220(4):417-21, 2012.

Cameron, N. The methods of axiological anthropometry. In: Falkner, F. \& Tanner, J. M. (Eds.). Human Growth. Vol 2. New York, London, Plenum Press, 1978. pp.35-90.

Carpenter, M. B. Core Text of Neuroanatomy. 4th ed. Baltimore, Williams \& Wilkins, 1991.

Drake, R. L.; Vogl, W. \& Mitchell, A. W. M. Gray's Anatomy for Students. Philadelphia, Churchill Livingstone/Elsevier, 2010.

Egaas, B.; Courchesne, E. \& Saitoh, O. Reduced size of corpus callosum in autism. Arch. Neurol., 52(8):794-801, 1995.
Erdogan, N.; Ulger, H.; Tuna, I. \& Okur, A. A novel index to estimate the corpus callosum morphometry in adults: callosal/ supratentorial-supracallosal area ratio. Diagn. Interv. Radiol., 11(4):179-81, 2005.

Farahani, R. M. \& Nooranipour, M. Anatomy and anthropometry of human stapes. Am. J. Otolaryngol., 29(1):42-7, 2008.

Giedd, J. N.; Blumenthal, J.; Jeffries, N. O.; Rajapakse, J. C.; Vaituzis, A. C.; Liu, H.; Berry, Y. C.; Tobin, M.; Nelson, J. \& Castellanos, F. X. Development of the human corpus callosum during childhood and adolescence: a longitudinal MRI study. Prog. Neuropsychopharmacol. Biol. Psychiatry, 23(4):571-88, 1999.

Gupta, T.; Singh, B.; Kapoor, K.; Gupta, M. \& Kochhar, S. Age and sex related variations in corpus callosal morphology. Nepal Med. Coll. J.,10(4):215-21, 2008. 
His, W. Die Formentwickelung des menschlichen Vorderhirns vom Ende des ersten bis zum Beginn des dritten Monats. Leipzig, S. Hirzel, 1889.

Hochstetter, F. Beiträge zur Entwicklungsgeschichte des menschlichen Gehirns. Vienna, Deuticke, 1919.

Lee, D. J.; Chen, Y. \& Schlaug, G. Corpus callosum: musician and gender effects. Neuroreport, 14(2):205-9, 2003.

Luders, E.; Rex, D. E.; Narr, K. L.; Woods, R. P.; Jancke, L.; Thompson, P. M.; Mazziotta, J. C. \& Toga, A. W. Relationships between sulcal asymmetries and corpus callosum size: gender and handedness effects. Cereb. Cortex, 13(10):1084-93, 2003.

Mourgela, S.; Anagnostopoulou, S.; Sakellaropoulos, A. \& Gouliamos, A. An MRI study of sex- and age-related differences in the dimensions of thecorpus callosum and brain. Neuroanat., 6:63-5, 2007.

National Health and Nutrition Examination Survey (NHANES). Anthropometry Procedures Manual. Atlanta, Center for Disease Control and Prevention, 2007. Available in: http:// www.cdc.gov/nchs/data/nhanes/nhanes_07_08/manual_an.pdf

Ozdemir, S. T.; Ercan, I.; Sevinc, O.; Guney, I.; Ocakoglu, G.; Aslan, E. \& Barut, C. Statistical shape analysis of differences in the shape of the corpus callosum between genders. Anat. Rec. (Hoboken), 290(7):825-30, 2007.

Patestas, M. \& Gartner, L. P. A Textbook of Neuroanatomy. Oxford, Wiley-Blackwell, 2006.

Poltana, P.; Poulpanich, N.; Withyachumnarnkul, B.; Suriyaprapadilok, L. \& Inthisean, P. No Significant Sexual Dimorphism of the Corpus Callosum in Thai Subjects: A Study Using Stained Plastinated Brain Slices. ScienceAsia, 27:2039, 2001.

Rakic, P. \& Yakovlev, P. I. Development of the corpus callosum and cavum septi in man. J. Comp. Neurol., 132(1):45-72, 1968.

Robinette, K.; Blackwell, S.; Daanen, H.; Fleming, S.; Boehmer, M.; Brill, T.; Hoeferlin, D. \& Burnsides, D. Civilian American and European Surface Anthropometry Resource (CAESAR). Final Report. Vol. I: Summary, AFRL-HE-WP-TR-2002-0169. Wright-Patterson Air Force Base, OH, Air Force Research Laboratory, Human Effectiveness Directorate, Crew System Interface Division, 2002.

Snell, R. S. Clinical Neuroanatomy. 7th ed. Philadelphia, Wolters Kluwer Health/Lippincott Williams \& Wilkins, 2010.

Sullivan, E. V.; Rosenbloom, M. J.; Desmond, J. E. \& Pfefferbaum, A. Sex differences in corpus callosum size: relationship to age and intracranial size. Neurobiol. Aging, 22(4):603-11, 2001.

Waxman, S. G. Clinical Neuroanatomy. 27th ed. London, McGraw Hill, 2009.

\author{
Correspondence to: \\ Reza Mastery Farahani \\ Department of Anatomy \\ Shahid Beheshti University of Medical Sciences \\ Faculty of Medicine \\ Tehran \\ IRAN
}

Email: mohammadyassin@ymail.com

Received: 25-05-2014

Accepted: 22-10-2014 